\title{
Internet Usage by Polish Patients With Multiple Sclerosis: A Multicenter Questionnaire Study
}

Andrzej Potemkowski ${ }^{1^{*}}, \mathrm{MD}, \mathrm{PhD}$; Waldemar Brola ${ }^{2^{*}}, \mathrm{MD}$, PhD; Anna Ratajczak ${ }^{3 *}, \mathrm{MD}, \mathrm{PhD}$; Marcin Ratajczak ${ }^{4^{*}}$, MD, PhD; Jacek Zaborski ${ }^{5 *}$, MD, PhD; Elżbieta Jasińska ${ }^{6}, \mathrm{MD}, \mathrm{PhD}$; Anna Pokryszko-Dragan ${ }^{7^{*}}$, MD, PhD; Ewa Gruszka $^{7^{*}}, \mathrm{MD}, \mathrm{PhD}$; Marta Dubik-Jezierzańska ${ }^{8^{*}}, \mathrm{MD}, \mathrm{PhD}$; Aleksandra Podlecka-Piętowska ${ }^{9^{*}}, \mathrm{MD}, \mathrm{PhD}$; Monika Nojszewska $^{9 *}$, MD, PhD; Krystyna Gospodarczyk-Szot ${ }^{9 *}$, MD; Adam Stępieñ ${ }^{10^{*}}, \mathrm{MD}$, PhD; Katarzyna Gocyła-Dudar ${ }^{10^{*}}$, MD; Marzena Maciagoowska-Terela ${ }^{10^{*}}, \mathrm{MD}, \mathrm{PhD}$; Jacek Wence ${ }^{11^{*}}, \mathrm{MD}, \mathrm{PhD}$; Radosław Kaźmierski ${ }^{11^{*}}, \mathrm{MD}, \mathrm{PhD}$; Alina Kułakowska ${ }^{12^{*}}, \mathrm{MD}, \mathrm{PhD}$; Katarzyna Kapica-Topczewska ${ }^{12^{*}}, \mathrm{MD}, \mathrm{PhD}$; Witold Pawełczak ${ }^{13^{*}}$, MD; Halina Bartosik-Psujek $^{14^{*}}, \mathrm{MD}, \mathrm{PhD}$

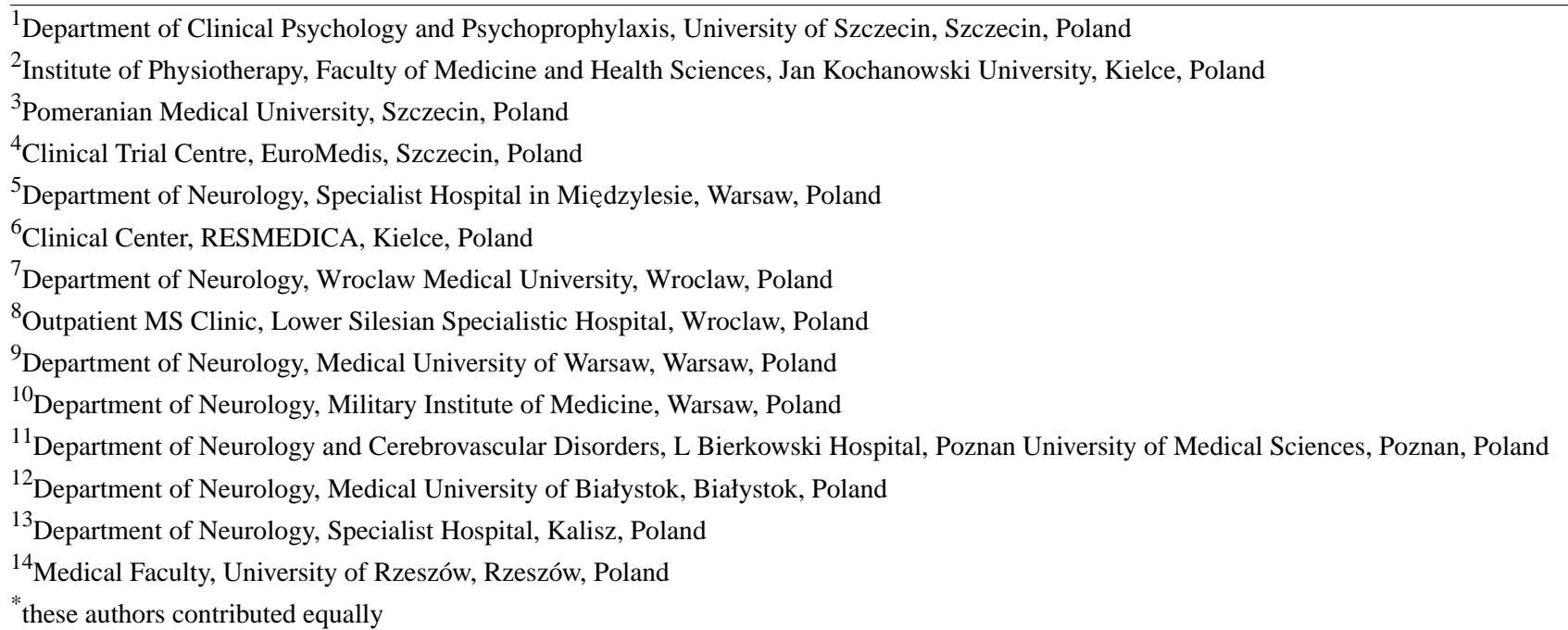

\section{Corresponding Author:}

Waldemar Brola, MD, PhD

Institute of Physiotherapy

Faculty of Medicine and Health Sciences

Jan Kochanowski University

IX Wieków Kielc 19

Kielce, 25-317

Poland

Phone: 48413902259

Fax: 48413902364

Email: wbrola@wp.pl

\section{Abstract}

Background: The internet is a source of knowledge and medium widely used in services that facilitate access to information and networking. Multiple sclerosis (MS) patients find the possibility of acquiring information relating to their condition particularly rewarding.

Objective: We aimed to identify Polish MS patients' preferences by analyzing a percentage of internet users and determining the most common search subjects and patients' approach to information on the internet. Disability connected with the condition, its duration, and other factors that influence patients' internet use were examined along with instances of relations established through the internet and their durability. 
Methods: The study examined 1045 patients (731 women, 314 men) treated in 10 Polish MS centers, of whom 932 (89.19\%) declared to be internet users. Their average age was 40.65 (SD 11.06) and average MS duration was 9.08 (SD 6.97) years. The study used a proprietary survey on information seeking, the range of searched subjects, and internet usage frequency.

Results: The majority of the patients (494/932, 53.0\%) used the internet 6-7 times per week and 4.3\% (40/932) declared they spent minimum 2 hours per day. The most commonly searched subjects were world news $(604 / 932,72.9 \%$ of patients using the internet); $60.8 \%$ (504/932) searched for information on their condition, particularly for new treatment methods (562/932, 67.8\%) and the course of illness $(520 / 932,62.7 \%)$. One's sex had no impact on internet usage (female vs male, odds ratio [OR] 1.13, 95\% CI 0.72-1.77), although a patient's age might, at varying degrees. We found several significant associations using a .05 significance level: a patient with higher education used the internet 9 times more often than one with primary education (OR 8.64, 95\% CI 3.31-22.57); lasting relationships increased chances of internet usage by 10-fold compared to widowers (OR 0.12, 95\% CI 0.05-0.31); living in a city with a population over 100,000 increased chances by nearly 6 times compared with the countryside (OR 5.59, 95\% CI 2.72-11.48); the relapsing-remitting MS type saw a 2-fold increase compared with the primary progressive MS type (OR 0.47, 95\% CI 0.29-0.75); and those needing assistance were 2 times less likely to use the internet than patients who could move independently (OR 0.53, 95\% CI 0.31-0.89). More than half of the patients (489/932, 52.5\%) did not discuss the information found on the internet with their neurologists; 15.9\% (148/932) believed that relationships established through the internet can be stable.

Conclusions: The majority of Polish patients use the internet as a crucial information source on their condition and innovative treatment methods. The internet can be helpful in establishing new relationships, which are usually short-lived. Polish patients do not frequently discuss the information gathered on the internet with their doctors.

(Interact J Med Res 2019;8(1):e11146) doi: 10.2196/11146

\section{KEYWORDS}

multiple sclerosis; internet; information seeking; doctor-patient relationship

\section{Introduction}

The internet is one of the most popular sources for information and entertainment. Multiple sclerosis (MS) makes day-to-day functioning difficult because it limits interpersonal relationships and presence in societal life. Communication and exchange of information, ideas, and feelings' grow more and more troublesome [1]. Studies on direct verbal communication show that almost half of the examined participants $(46 \%)$ claimed poor or very poor ability to undertake social roles. Half of the participants claimed they were unhappy with their interpersonal activity [1]. Communication problems indeed influence restrictions in many social roles common in adult life, including work, home management, and leisure activities. Yorkston et al identified 5 variables (cognitive skills, speech severity, speech usage, physical activity, and education) that were the most important predictors of communication participation [1]. These restrictions would seem to be an important target for intervention.

Some studies reveal that internet use leads to deepened psychopathology, alienation, and loneliness, but those results are ambiguous. In their longitudinal studies of 1998, Kraut et al initially claimed that using the internet contributed to one's sense of loneliness and higher depression rates, but when the same trial was repeated in 2002 , it failed to confirm previous conclusions $[2,3]$.

The subject of patients' condition is of particular interest to them; the amount and incomprehensibility of medical terminology and the uncertainty connected with the clinical course of the disease all serve as motivation for further research on the internet. From the very time the internet became widely accessible, scientists have conducted studies on human behavior, the influence of the internet on one's life and the correlations between its usage and one's living standards and psychical and societal life, as well as those suffering from MS [4,5,6,7].

Internet communication may happen synchronously or asynchronously. Forum users may be online at the same time and communicate verbally on a given subject, having relatively high control over their answer and the ability to edit it if needed [8].

From a psychological point of view, verbal communication, with sounds and vision, is preferred. It is important for those suffering from MS as a supporting tool or even in psychological therapy $[9,10]$. Nevertheless, text dialogue grants more comfort to those having difficulties with communication because it provides anonymity and allows one to stop the contact at any given moment [11]. Atreja et al indicated that MS patients typically search for information right before or after a doctor's appointment and use the information available online to check medical terminology [12]. Hay et al showed that majority of MS patients surfed the internet before their first appointment [13]. Even though the information found on the internet cannot replace that provided by a doctor, two-thirds of patients were reluctant to share the information gained independently with their doctors-which suggests that patients fear that their research could be understood as a lack of trust toward their doctors [13]. The quality and content found online and available to MS patients were assessed as varied, although some websites did offer almost all crucial information [14].

The studies also focused on personal traits, language barriers, and the impact other illnesses have on societal life [15-18]. The results indicated that the internet might have a positive impact on establishing new contacts, especially in the case of patients struggling with their symptoms. In high neuroticism, a limited 
amount of stimuli proved to be helpful in communication and relationship building [15]. Establishing and maintaining new relations constitutes one of the most significant psycho-social needs of MS patients that can be met through internet usage [18-20].

The aim of our study was to determine the percentage of Polish MS patients using the internet, the most commonly searched subjects, patients' approach to the information found on the internet, and assess the impact of the condition's duration, different levels of disability, and other demographic factors on the frequency and durability of relationships established online.

\section{Methods}

\section{Design}

We carried out the assessment in 2 stages: (1) the pilot study (drafting and verification of the questionnaire) and (2) the survey proper. The first stage (September-December 2015) consisted of a pilot examination in a group of $83 \mathrm{MS}$ patients who declared to be using the internet; its aim was to evaluate the research tool developed for the study [18]. The questionnaire was developed by the authors and based on their experiences. The data collection was carried out at the Department of Clinical Psychology and Psychoprophylaxis of the University of Szczecin in Szczecin. The second stage included the proper survey conducted in 10 centers of MS diagnosis and treatment in 7 Voivodeships of Poland ( 8 clinical wards and outpatient MS clinics, an MS rehabilitation center, and a center for clinical trials related to MS). An anonymous questionnaire containing 11 questions on demographic data and 14 connected to one's internet usage was filled out by patients during their appointments.

\section{Setting and Participants}

Participants were recruited between February 2016 and December 2016 for the cross-sectional study. Patients were invited to fill out a paper version of the survey. The study included patients over the age of 18 years suffering from MS (clinically defined according to the McDonald criteria, 2010). Informed consent was obtained from all individual participants included in the original clinical studies.

\section{Statistical Analysis}

All the continuous variables were verified owing to normal distribution with the Kolmogorov-Smirnov test. They were described using means, SDs, medians, quartiles, and minimal and maximal values. Verification of statistical differences between 2 groups was done using the Student $t$ test and Mann-Whitney $U$ test. For many groups, the analysis of variance and Kruskal-Wallis tests were used. Discontinuous variables were described using the quantity and frequency of occurrence. For studying statistical relations among discontinuous variables, the Pearson chi-square test or the Fisher exact test were used.
For studying correlations among discontinuous variables, sequential and nominal (dummy variables: 0/1) and continuous variables the Pearson or Spearman rank correlations were used. The results were described using the correlation coefficient $r$ and probability $P$. For the Pearson correlation, the regression line equations were also provided. A $P$ value of $<.05$ was considered statistically significant. Data were analyzed using SPSS software, version 17.0 (2008; SPSS Inc, Chicago, IL, USA).

\section{Ethics Approval}

The study received ethics approval from the Department of Psychology, University of Szczecin Ethics Committee (\#17/2015), and all participants received explanations of the study objectives and signed informed consents.

\section{Results}

The study involved 1045 people (731 female and 314 male) with an average age of 40.65 (SD 11.06) years. The average MS duration was 9.08 (SD 6.97) years (Table 1). The majority of participants $(89.19 \%)$ used the internet $(932 / 1045$ patients: 652 females and 280 males); only $10.81 \%$ (113/1045 patients) did not use the internet. In the internet user group, $53.0 \%$ (494/932) stated they used the internet more than 4-5 times a week, and 56.4\% (526/932) of the patients spent an average of 1-4 hours per week browsing the internet. Only $4.7 \%$ (44/932) of the patients claimed to use the internet more than 14 hours per week (at least 2 hours per day; Table 2).

Subjects that were most commonly searched were world news (604/932, 72.9\% of patients using the internet); 60.8\% (504/932) searched for information on their disease and 54.5\% (452/932) looked for information on treatment. Over half of the patients examined $(423 / 932,51.0 \%)$ communicated with others via the internet. Only $1.8 \%(15 / 932)$ used it to search for job offers (Table 3).

Nearly $15 \%$ (120/932) of participants used the internet to establish new relationships and find new communities of MS patients. Relationships developed through the internet were deemed to be unstable by $32.9 \%$ (307/932) of patients and durable by $15.9 \%$ (148/932); $28.8 \%$ (268/932) of the examined patients sustained such relations. Only $13.2 \%$ (123/932) reported meeting other MS patients online.

While searching for information on MS, 67.8\% (562/932) of the patients were looking for data on innovative treatment methods; $62.7 \%$ (520/932) focused on the course of the disease and $41.9 \%$ (347/932) on estimates concerning lifespan and diagnostic methods (Table 4).

The study showed that internet usage does not depend on sex (female vs male, odds ratio [OR] $1.13,95 \%$ CI 0.72-1.77), although it might depend on age (Table 5). 
Table 1. Demographic and clinical characteristics of study participants $(\mathrm{N}=1045)$.

\begin{tabular}{|c|c|c|c|}
\hline Characteristics & $\mathrm{MS}^{\mathrm{a}}$ internet users $(\mathrm{n}=932)$ & MS internet nonusers $(n=113)$ & $P$ value \\
\hline Patients invited, $n(\%)$ & $932(89.18)$ & $113(10.81)$ & $<.001$ \\
\hline Female & $652(62.39)$ & $79(7.55)$ & .99 \\
\hline Male & $280(26.79)$ & $34(3.25)$ & \\
\hline Age (years), mean (SD) & $40.51(10.94)$ & $41.84(12.05)$ & .23 \\
\hline Female & $40.64(11.12)$ & $41.24(12.38)$ & .6 \\
\hline Male & $40.24(10.54)$ & $43.22(11.29)$ & .12 \\
\hline Disease duration (years), mean (SD) & $8.99(6.86)$ & $9.81(7.87)$ & .24 \\
\hline Female & $9.13(7.00)$ & $10.08(7.82)$ & .26 \\
\hline Male & $8.62(6.69)$ & $9.17(8.01)$ & .66 \\
\hline Education, $\mathbf{n}(\%)$ & & & $<.001$ \\
\hline Primary & $36(3.9)$ & $8(7.1)$ & \\
\hline Secondary & $358(38.4)$ & $34(30.1)$ & \\
\hline Higher & $409(43.9)$ & $32(28.3)$ & \\
\hline Vocational & $129(13.9)$ & $39(34.5)$ & \\
\hline Marital status, $n(\%)$ & & & .01 \\
\hline Married & $612(65.7)$ & $73(64.6)$ & \\
\hline Divorced & $84(9.0)$ & $11(9.7)$ & \\
\hline Unmarried & $217(23.3)$ & $21(18.6)$ & \\
\hline Widow or widower & $19(2.0)$ & $8(7.1)$ & \\
\hline Employment, n (\%) & & & .003 \\
\hline Full-time & $508(54.4)$ & $55(48.7)$ & \\
\hline Part-time & $65(6.9)$ & $6(5.3)$ & \\
\hline Pension & $300(32.2)$ & $34(30.1)$ & \\
\hline Never worked & $59(6.4)$ & $18(15.9)$ & \\
\hline Residence, $\mathbf{n}(\%)$ & & & .29 \\
\hline Countryside & $361(38.7)$ & $44(38.9)$ & \\
\hline City of up to 10,000 & $145(15.6)$ & $17(15.0)$ & \\
\hline City of up to 100,000 & $165(17.7)$ & $13(11.5)$ & \\
\hline City of over 100,000 & $261(28.0)$ & $39(34.5)$ & \\
\hline Living with, n (\%) & & & .3 \\
\hline Partner and children & $467(50.1)$ & $56(49.6)$ & \\
\hline Partner & $154(16.5)$ & $18(15.9)$ & \\
\hline Children & $50(5.4)$ & $5(4.4)$ & \\
\hline Parents & $162(17.4)$ & $15(13.3)$ & \\
\hline Alone & $99(10.6)$ & $19(16.8)$ & \\
\hline MS type, n (\%) & & & .80 \\
\hline Relapsing-remitting multiple sclerosis & $360(38.6)$ & $45(39.8)$ & \\
\hline Secondary progressive multiple sclerosis & $348(37.3)$ & $44(38.9)$ & \\
\hline Primary progressive multiple sclerosis & $224(24.0)$ & $24(21.2)$ & \\
\hline Mobility, n (\%) & & & .88 \\
\hline Without assistance & $736(79.0)$ & $90(79.7)$ & \\
\hline
\end{tabular}




\begin{tabular}{lll}
\hline Characteristics & $\mathrm{MS}^{\mathrm{a}}$ internet users (n=932) & MS internet nonusers (n=113) $P$ value \\
\hline Independently, with orthopedic device & $135(14.5)$ & $17(15.0)$ \\
With assistance & $61(6.6)$ & $6(5.3)$ \\
\hline
\end{tabular}

${ }^{\mathrm{a}} \mathrm{MS}$ : multiple sclerosis.

Table 2. Internet use by patients with multiple sclerosis $(n=932)$.

\begin{tabular}{lc}
\hline Internet use & Patients, $\mathrm{n}(\%)$ \\
\hline Frequency of browsing websites on the internet & $78(9.4)$ \\
Once a week & $120(12.9)$ \\
$2-3$ times a week & $130(13.9$ \\
$4-5$ times a week & $494(53.0)$ \\
More often & $110(11.8)$ \\
Difficult to determine & $526(56.4)$ \\
Hours on the internet per week & $182(19.5)$ \\
$1-4$ & $57(6.1)$ \\
$5-7$ & $44(4.7)$ \\
$8-14$ & $123(13.2)$ \\
More & \\
Difficult to determine & \\
\hline
\end{tabular}

Table 3. Internet services used by Polish patients with multiple sclerosis ( $\mathrm{n}=932)$.

\begin{tabular}{lc}
\hline Service & Patients, $\mathrm{n}(\%)$ \\
\hline World news & $604(72.9)$ \\
MS ${ }^{\mathrm{a}}$ information & $504(60.8)$ \\
Shopping & $458(55.6)$ \\
Treatment information & $452(54.5)$ \\
Communication & $423(51.0)$ \\
Entertainment, movies & $408(49.2)$ \\
New acquaintances & $120(14.5)$ \\
Meeting people and communities with MS & $117(14.1)$ \\
Other-job seeking & $15(1.8)$ \\
Other-scientific research & $11(1.3)$ \\
\hline
\end{tabular}

${ }^{\mathrm{a}} \mathrm{MS}$ : multiple sclerosis. 
Table 4. Type of health information sought about multiple sclerosis at the time of most recent search ( $n=932)$.

\begin{tabular}{|c|c|}
\hline Type of health information sought & Patients, n (\%) \\
\hline Innovative treatment methods & $562(67.8)$ \\
\hline Course of $\mathrm{MS}^{\mathrm{a}}$ & $520(62.7)$ \\
\hline Medication reviews (efficiency) & $407(49.1)$ \\
\hline Diagnostic methods in MS & $347(41.86)$ \\
\hline Prognosis and lifespan & $347(41.9)$ \\
\hline MS treatment costs & $336(40.5)$ \\
\hline MS diagnosis—criteria & $324(39.1)$ \\
\hline New medication—analysis & $285(34.4)$ \\
\hline MS treatment centers' reviews & $238(28.7)$ \\
\hline MS doctors' reviews & $196(23.6)$ \\
\hline Stem cells treatment-results & $192(23.2)$ \\
\hline Alternative methods-reviews & $184(22.2)$ \\
\hline MS and pregnancy & $158(19.1)$ \\
\hline Treatment center using stem cells & $158(19.1)$ \\
\hline MS and marriage & $104(12.6)$ \\
\hline MS and sexuality & $97(11.7)$ \\
\hline Raising children & $96(11.6)$ \\
\hline MS and chronic venous insufficiency (results) & $54(6.5)$ \\
\hline MS and diet & $5(0.6)$ \\
\hline
\end{tabular}

${ }^{\mathrm{a}} \mathrm{MS}$ : multiple sclerosis.

Higher education was associated with almost a 9-fold increase in internet usage compared with primary education (OR 8.64, 95\% CI 3.31-22.57) and widows or widowers tended to use it 10 times less often than those in a partner relationship (OR 0.12 , 95\% CI 0.05-0.31). Living in a city with a population greater than 100,000 increased the chances 6-fold compared with living in the countryside (OR 5.59, 95\% CI 2.72-11.48). Patients requiring assistance were 2 times less likely to use the internet compared with those that were able to move independently (OR $0.53,95 \%$ CI 0.31-0.89) and patients with relapsing-remitting MS were 2 times less likely to use the internet than those suffering from primary progressive MS (OR 0.47, 95\% CI $0.29-0.75$ ). A stable course of condition (with no relapses) increased the chances by 1.5 times compared with relapsing-remitting MS (OR 1.50, 95\% CI 0.87-2.57).

Over half of the participants $(489 / 932,52.5 \%)$ did not discuss the information on MS found on the internet with their neurologists. Moreover, 75.2\% (676/932) recommend other patients to use the internet, but $82.4 \%$ (768/932) warned about the application of data about MS found online. The study also evaluated the credibility of the websites according to the patients (0: unreliable and 10: reliable). The participants of this part of the study decided that the most reliable websites belonged to the MS communities and other patients suffering from MS, that is, blogs (Table 6). 
Table 5. Internet usage according to sociodemographic and health-related factors.

\begin{tabular}{|c|c|c|c|}
\hline Categories & Odds ratio & $95 \% \mathrm{CI}$ & $P$ value \\
\hline Sex: men vs women & 1.13 & $0.72-1.77$ & .59 \\
\hline \multicolumn{4}{|l|}{ Age (years) } \\
\hline $33-48$ vs $<33$ & 0.31 & $0.13-0.75$ & .01 \\
\hline$>48$ vs $<33$ & 0.08 & $0.03-0.18$ & $<.001$ \\
\hline \multicolumn{4}{|l|}{ Duration $\mathbf{M S}^{\mathrm{a}}$ (years) } \\
\hline $4-12$ vs $<4$ & 1.09 & $0.62-1.91$ & .78 \\
\hline$>12$ vs $<4$ & 0.48 & $0.27-0.87$ & $<.001$ \\
\hline \multicolumn{4}{|l|}{ Education } \\
\hline Secondary vs primary & 1.94 & $0.83-4.51$ & .13 \\
\hline Higher vs primary & 8.64 & $3.31-22.57$ & $<.001$ \\
\hline Vocational vs primary & 0.68 & $0.29-1.64$ & .39 \\
\hline \multicolumn{4}{|l|}{ Employment } \\
\hline Part-time vs full-time & 0.25 & $0.11-0.55$ & .001 \\
\hline Pension vs full-time & 0.18 & $0.11-0.29$ & $<.001$ \\
\hline Never worked vs full-time & 0.49 & $0.18-1.36$ & .17 \\
\hline \multicolumn{4}{|l|}{ Marital status } \\
\hline Divorced vs married & 0.91 & $0.46-1.79$ & .78 \\
\hline Miss or bachelor vs married & 2.31 & $1.23-4.34$ & .01 \\
\hline Widow or widower vs married & 0.12 & $0.05-0.31$ & $<.001$ \\
\hline \multicolumn{4}{|l|}{ Residence } \\
\hline City of up to 10,000 vs countryside & 0.96 & $0.57-1.60$ & .87 \\
\hline City of up to 100,000 vs countryside & 3.47 & $1.68-7.18$ & .001 \\
\hline City of over 100,000 vs countryside & 5.59 & $2.72-11.48$ & $<.001$ \\
\hline \multicolumn{4}{|l|}{ MS course } \\
\hline Stable without relapse vs with relapse & 1.50 & $0.87-2.57$ & .14 \\
\hline Progressive vs with relapse & 0.47 & $0.29-0.75$ & .002 \\
\hline \multicolumn{4}{|l|}{ Mobility } \\
\hline Independently with devices vs without help & 0.53 & $0.31-0.89$ & .02 \\
\hline With help vs without help & 0.18 & $0.10-0.33$ & $<.001$ \\
\hline
\end{tabular}

${ }^{\mathrm{a}} \mathrm{MS}$ : multiple sclerosis.

Table 6. Credibility of websites dealing with multiple sclerosis.

\begin{tabular}{lll}
\hline Internet website & $\mathrm{n}$ & Average credibility (0-10) \\
\hline MS $^{\text {a communities' websites }}$ & 153 & 7.25 \\
Blogs written by patients & 151 & 6.26 \\
MS services' websites & 147 & 5.47 \\
Doctors' blogs or websites & 130 & 6.37 \\
Foreign websites & 115 & 6.65 \\
\hline
\end{tabular}

${ }^{\mathrm{a}} \mathrm{MS}$ : multiple sclerosis. 


\section{Discussion}

An examination of how MS patients use the internet may result in a range of observations and conclusions, as shown in previous findings [4,5,6,21]. Our multicenter study confirmed that discovering the preferences of Polish MS patients in connection to internet usage has many practical implications.

As the study revealed, the way Polish individuals suffering from MS use the internet does not depend on their sex but on their age. Similar dependency was also found in the case of the general Polish population [22].

Our study shows that patients with shorter disease duration tend to seek information on the internet more often, which confirms the conclusions of studies on the importance of the information presented to newly diagnosed patients with MS [23,24]. Although the internet was a significant source for obtaining MS-related information, most participants did not find this information suitable for discussion with their doctors, which may stem from the uncertainty connected with treatment methods, the course of the disease, and its possible outcomes. Lack of communication involving the information found on the internet might constitute a potential harmful factor for the patient-doctor relationship.

The accuracy and reliability of health information introduced on the internet and its impact on health care have been frequently discussed $[5,6,7,9]$. The majority of the examined patients claimed that they pay attention to the information source and would rate its credibility. Websites belonging to MS communities were deemed the most reliable -7.25 on a scale of $0-10$, which underlines the importance of discussing the information found online with a medical professional, as well as the significance of the subject on patient-doctor relationships and impact on adherence [21,25].

Cyberpsychological studies are helpful in evaluating whether more engaged patients see medical improvement stemming from deeper adherence and a better understanding of preventive examinations. It is known that the availability of information changes the patients' expectations in the area of decision making during the treatment [26,27]. All medical treatments, including those for MS, become a cooperative process led by both doctors and their patients. The latter is given a chance to engage and actively participate in choices regarding their health and condition [28].

The internet also provides a new field for innovative forms of psychological help and control of medical suggestions (telemedicine). Auto-diagnosis, including that for MS, is a separate risk connected with the accessibility of the internet, so a person who believes they are suffering from a disease based on information found online should consult a neurologist and follow a doctor's professional opinion.
MS websites (eg, SMsocialnetwork.com) were perceived by patients to be a useful tool to support health-related coping and social interaction and may suggest a new kind of therapeutic alliance between physicians and people with MS [29].

Building new relationships online has long been a matter of interest for psychologists, who recognize its potential dangers and undeniable advantages facilitating social life for those finding direct communication difficult $[4,15,19]$. In the case of MS patients, particularly in the later stages of the disease, maintaining contact with others through internet communication from their homes might be a helpful tool for coping with isolation and its negative impact on one's life [1].

Studies have confirmed that Polish MS patients use the internet to build new relationships, which usually remain outside of the direct communication zone. This might be caused by specific methods of taking care of oneself and one's family in the face of illness [26]. A similar examination conducted on bigger groups of MS patients confirmed that certain Web-based environments might impact one's standard of living, which is caused mainly by meeting new people and maintaining contact with them $[2,3,17]$.

Our examination of $1045 \mathrm{MS}$ patients resulted in an objective assessment of many aspects of data collection and was helpful in defining the preferred form of websites. The data on internet browsing behaviors, including the frequency and usage of internet services, facilitate the development of websites to be tailored to the needs and habits of the audience. It is important to note that certain MS patients may encounter problems accessing the websites owing to disabilities, disease symptoms, difficulties with vision, cognitive disorders, and impaired memory, as indicated before [12]. Such adjustments might prove supportive and helpful for MS patients who wish to experience modern medicine's benefits-personalization and active participation in the treatment process.

Our study, the first of its kind in Poland, describes the relationship between the clinical and demographic factors of MS patients and their approach and methods applied when searching the internet for information. The results suggest that patients are eager to use the internet to learn about their condition. Although the information found online is rarely discussed with doctors, the possibility of maintaining contact between a patient and their doctor may grant the patient better access to credible information, which may have a positive impact on his or her treatment process. The availability of internet data might aid in the improvement and personalization of health care, answering patients' specific needs and providing information tailored to one's stage of disease, disability level, employment situation, and computer skills (including the ability to use the internet).

\section{Authors' Contributions}

All authors contributed toward data analysis, drafting and revising the paper, and agree to be accountable for all aspects of the work. 


\section{Conflicts of Interest}

None declared.

\section{References}

1. Yorkston K, Baylor C, Amtmann D. Communicative participation restrictions in multiple sclerosis: associated variables and correlation with social functioning. J Commun Disord 2014;52:196-206 [FREE Full text] [doi:

10.1016/i.jcomdis.2014.05.005] [Medline: 24947986]

2. Kraut R, Patterson M, Lundmark V, Kiesler S, Mukopadhyay T, Scherlis W. Internet paradox. A social technology that reduces social involvement and psychological well-being? Am Psychol 1998 Sep;53(9):1017-1031. [Medline: 9841579]

3. Kraut R, Kiesler S, Boneva B, Cummings J, Helgeson V, Crawford A. Internet Paradox Revisited. J Soc Issues 2002;38(1):49-74.

4. Haase R, Schultheiss T, Kempcke R, Thomas K, Ziemssen T. Modern communication technology skills of patients with multiple sclerosis. Mult Scler 2013 Aug;19(9):1240-1241. [doi: 10.1177/1352458512471882] [Medline: 23388164]

5. Lejbkowicz I, Paperna T, Stein N, Dishon S, Miller A. Internet usage by patients with multiple sclerosis: implications to participatory medicine and personalized healthcare. Mult Scler Int 2010;2010:640749 [FREE Full text] [doi: 10.1155/2010/640749] [Medline: 22096625]

6. Hay M, Strathmann C, Lieber E, Wick K, Giesser B. Why patients go online: multiple sclerosis, the internet, and physician-patient communication. Neurologist 2008 Nov;14(6):374-381. [doi: 10.1097/NRL.0b013e31817709bb] [Medline: $\underline{19008743}$ ]

7. Wallace P. The Psychology of Internet. Cambridge: Cambridge University Press; 2016.

8. Sproull L, Kiesler S. Reducing Social Context Cues: Electronic Mail in Organizational Communication. Management Science 1986 Nov;32(11):1492-1512. [doi: 10.1287/mnsc.32.11.1492]

9. Boeschoten RE, Dekker J, Uitdehaag BMJ, Polman CH, Collette EH, Cuijpers P, et al. Internet-based self-help treatment for depression in multiple sclerosis: study protocol of a randomized controlled trial. BMC Psychiatry 2012 Sep 11;12:137 [FREE Full text] [doi: 10.1186/1471-244X-12-137] [Medline: 22967202]

10. Wardell L, Hum S, Laizner A, Lapierre Y. Multiple Sclerosis Patients' Interest in and Likelihood of Using Online Health-Care Services. International Journal of MS Care 2009 Jun;11(2):79-89. [doi: 10.7224/1537-2073-11.2.79]

11. McKenna K, Green A, Gleason M. Relationship Formation on the Internet: What's the Big Attraction? J Soc Issues 2002;58(1):9-31 [FREE Full text]

12. Atreja A, Mehta N, Miller D, Moore S, Nichols K, Miller H, et al. One size does not fit all: using qualitative methods to inform the development of an Internet portal for multiple sclerosis patients. AMIA Annu Symp Proc 2005:16-20 [FREE Full text] [Medline: $\underline{16778993}$ ]

13. Hay M, Strathmann C, Lieber E, Wick K, Giesser B. Why patients go online: multiple sclerosis, the internet, and physician-patient communication. Neurologist 2008 Nov;14(6):374-381. [doi: 10.1097/NRL.0b013e31817709bb] [Medline: $\underline{19008743]}$

14. Harland J, Bath P. Assessing the quality of websites providing information on multiple sclerosis: evaluating tools and comparing sites. Health Informatics J 2007 Sep;13(3):207-221. [doi: 10.1177/1460458207079837] [Medline: 17711882]

15. Amichai-Hamburger Y, Wainapel G, Fox S. “On the Internet no one knows I'm an introvert”: extroversion, neuroticism, and Internet interaction. Cyberpsychol Behav 2002 Apr;5(2):125-128. [doi: 10.1089/109493102753770507] [Medline: $\underline{12025878]}$

16. Blumer T, Doering N. Are we the same online? The expression of the five factor personality traits on the computer and the Internet. CP 2012;6(3). [doi: 10.5817/CP2012-3-5]

17. Lee E, Lee L, Jang J. Internet for the internationals: effects of internet use motivations on international students' college adjustment. Cyberpsychol Behav Soc Netw 2011;14(7-8):433-437. [doi: 10.1089/cyber.2010.0406] [Medline: 21117984]

18. Potemkowski A, Janac A, Brola W. Using the Internet for people with multiple sclerosis. Pol Przegl Neurol 2017;13:1-6 [FREE Full text]

19. Monnier J, Laken M, Carter CL. Patient and caregiver interest in internet-based cancer services. Cancer Pract 2002;10(6):305-310. [Medline: 12406053]

20. Hall A. Audience Personality and the Selection of Media and Media Genres. Media Psychology 2005 Nov;7(4):377-398. [doi: 10.1207/S1532785XMEP0704 4]

21. Hobart J, Lamping D, Fitzpatrick R, Riazi A, Thompson A. The Multiple Sclerosis Impact Scale (MSIS-29): a new patient-based outcome measure. Brain 2001 May;124(Pt 5):962-973. [Medline: 11335698]

22. Haase R, Schultheiss T, Kempcke R, Thomas K, Ziemssen T. Use and acceptance of electronic communication by patients with multiple sclerosis: a multicenter questionnaire study. J Med Internet Res 2012 Oct 15;14(5):e135 [FREE Full text] [doi: 10.2196/jmir.2133] [Medline: 23069209]

23. Batorski D. Technologies and media in homes in the lives of Poles. In: Czapiski J, Panek T, editors. Social Diagnosis. The conditions and quality of Poles' lives. Warsaw: Social Monitoring Council; 2015:373-395. 
24. Lode K, Larsen JP, Bru E, Klevan G, Myhr KM, Nyland H. Patient information and coping styles in multiple sclerosis. Mult Scler 2007 Jul;13(6):792-799. [doi: 10.1177/1352458506073482] [Medline: 17613608]

25. Wollin J, Dale H, Spenser N, Walsh A. What People with Newly Diagnosed MS (and their Families and Friends) Need to Know. International Journal of MS Care 2000 Oct;2(3):29-39 [FREE Full text] [doi: 10.7224/1537-2073-2.3.29]

26. Zettl UK, Bauer-Steinhusen U, Glaser T, Hechenbichler K, Limmroth V, Study Group. Evaluation of an electronic diary for improvement of adherence to interferon beta- $1 \mathrm{~b}$ in patients with multiple sclerosis: design and baseline results of an observational cohort study. BMC Neurol 2013 Sep 06;13:117 [FREE Full text] [doi: 10.1186/1471-2377-13-117] [Medline: $\underline{24011220]}$

27. Kossakowska M, Zemła-Sieradzka L. Some positive aspects of coping with chronic illness in patients with multiple sclerosis. Post Psychiatr Neurol 2011;20(4):259-267 [FREE Full text]

28. Frosch DL, Kaplan RM. Shared decision making in clinical medicine: past research and future directions. Am J Prev Med 1999 Nov;17(4):285-294. [Medline: 10606197]

29. Lavorgna L, Russo A, De Stefano M, Lanzillo R, Esposito S, Moshtari F, et al. Health-Related Coping and Social Interaction in People with Multiple Sclerosis Supported by a Social Network: Pilot Study With a New Methodological Approach. Interact J Med Res 2017 Jul 14;6(2):e10. [doi: 10.2196/ijmr.7402]

\section{Abbreviations}

MS: multiple sclerosis

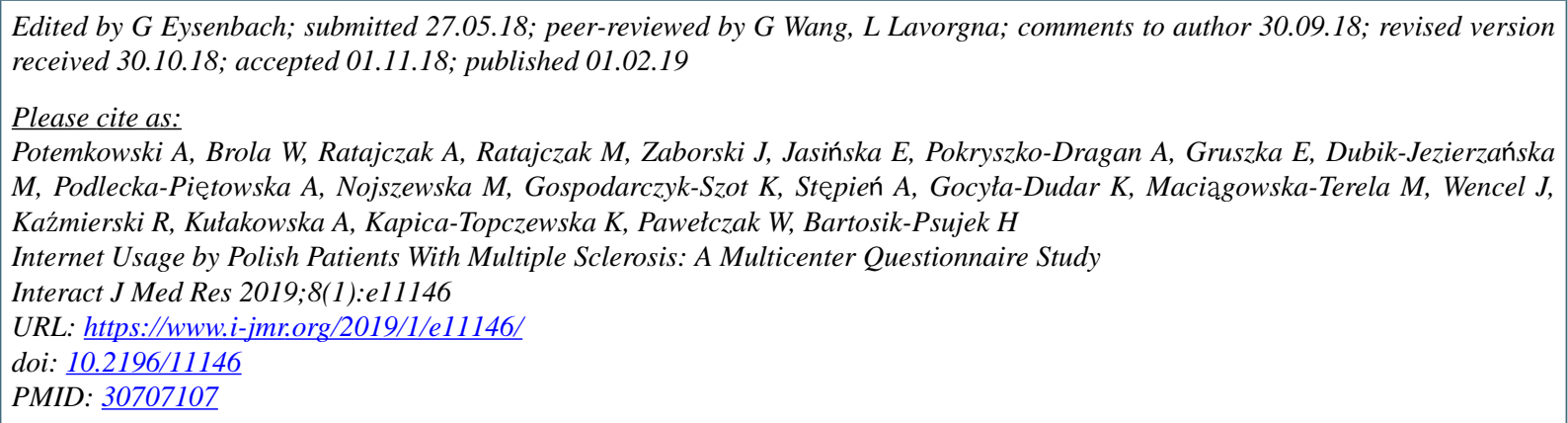

(CAndrzej Potemkowski, Waldemar Brola, Anna Ratajczak, Marcin Ratajczak, Jacek Zaborski, Elżbieta Jasińska, Anna Pokryszko-Dragan, Ewa Gruszka, Marta Dubik-Jezierzańska, Aleksandra Podlecka-Piętowska, Monika Nojszewska, Krystyna Gospodarczyk-Szot, Adam Stępień, Katarzyna Gocyła-Dudar, Marzena Maciągowska-Terela, Jacek Wencel, Radosław Kaźmierski, Alina Kułakowska, Katarzyna Kapica-Topczewska, Witold Pawełczak, Halina Bartosik-Psujek. Originally published in the Interactive Journal of Medical Research (http://www.i-jmr.org/), 01.02.2019. This is an open-access article distributed under the terms of the Creative Commons Attribution License (https://creativecommons.org/licenses/by/4.0/), which permits unrestricted use, distribution, and reproduction in any medium, provided the original work, first published in the Interactive Journal of Medical Research, is properly cited. The complete bibliographic information, a link to the original publication on http://www.i-jmr.org/, as well as this copyright and license information must be included. 